\title{
New rural dynamics and challenges in the Global South
}

\author{
T. Rauch ${ }^{1}$, M. Schmidt ${ }^{2}$, and D. Segebart ${ }^{1}$ \\ ${ }^{1}$ Institut für Geographische Wissenschaften, Freie Universität Berlin, Germany \\ ${ }^{2}$ Institut für Wirtschafts- und Kulturgeographie, Leibniz Universität Hannover, Germany
}

Correspondence to: D. Segebart (doerte.segebart@fu-berlin.de)

Received: 30 July 2014 - Accepted: 19 August 2014 - Published: 11 December 2014

\section{Introduction}

Dealing with rural areas in the Global South must be a central concern of geographical development research in the 21st century. Major challenges for the global community, such as the unsolved energy and food questions, the migration of people and increasing natural hazards as a result of climate change processes, are fundamentally linked with rural areas. Most natural resources - biotic and abiotic - are located in the rural environment, which provides land for the production of energy, raw materials and foods, as well as for various constructions, communication lines and production units. The rural environment is also the main source area for people migrating to cities or abroad to improve their living conditions or ensure survival, and it is closely linked with processes of climate change both as an amplifying and mitigating factor and as susceptible to its effects. To underestimate the relevance of the rural in academia or politics is dangerous and irresponsible.

The price hike in agricultural commodities of 2008/09 and the related hunger riots in many countries of the Global South awakened politicians, academics and business people, and brought increased attention to agricultural and rural development from many sides. As a result, international and national capital (re)discovered land and agriculture as sources for speculation and investment, agribusiness sought opportunities to contract small-scale farmers, and politicians called for a new "Green Revolution", with the World Bank, national governments and non-governmental agencies launching new concepts for promoting agricultural and rural development. While many representatives from development organisations celebrate the revival of the rural, critical scholars are drawn to the increasing commercialisation and commodification of rural resources and related risks to the livelihoods and even the survival of local people dependent on these resources; land acquisition by externals often means expropriation of the autochthonous population.

While geographical development studies have for some time invested more energy in the theoretical advancement of the discipline, they are now challenged by dramatic, emerging real-world trends and dynamics, which may require new research perspectives:

- The dynamics of global markets in agricultural commodities indicate a lasting trend towards increasing agricultural prices. While farming might become more attractive, it is doubtful that small-scale farmers can benefit from increasing demand, as financial market players, hedge funds, credit institutions, government and private investors have rapidly discovered agriculture as an attractive new business and a relevant venture for securing the increasing food and energy demands of their nations. It has become evident that rural development studies need to consider global market dynamics more than ever before.

- Besides the long-lasting trend towards degradation and an increasing scarcity of natural resources, there are severe additional risks to agricultural production and natural resource based livelihoods in many rural regions from the effects of climate change, such as irregular rainfall patterns, increased droughts and other extreme weather events. Therefore, the debate on natural risks and hazards needs to be interlinked with rural development studies.

- As a result of limited land resources and income options, the low price of agricultural products and neglect due to the neoliberal policies of their governments, many people have left rural areas while still maintaining links to their rural homesteads and their ancestors' land for the sake of social security, which cannot be 
easily found in the cities. From these livelihood dynamics, new systems of multi- or translocal livelihoods have emerged. Consequently, rural livelihood studies require a broader analytical focus.

- Last but not least, there is a changing institutional environment in most rural areas of the Global South, characterised by a withdrawal of government services, by privatisation and by decentralisation. While this has resulted in a service gap for people in many rural regions, in other places it has provided new opportunities for a more locally driven regional or territorial type of development. Whether or not the new market and investment dynamics and the threats related to natural resource degradation and climate variability can be managed by local people depends largely on the regulating capacity of the new local institutions. Thus, an analysis of these institutional dynamics has become an indispensable dimension of rural studies.

For an understanding of the complexity of rural dynamics, it is essential to analyse all mentioned aspects in context. On their own, neither conventional macro-level studies on global agricultural markets nor micro-level livelihood studies can fully explain the new rural dynamics, nor can an isolated climate change adaptation perspective or a mere institutional perspective. Consequently, this special issue looks at rural development from different perspectives as a step towards a multidimensional approach to geographical development studies.

Theo Rauch's contribution seeks to deepen and substantiate this argument by providing an overview on the different and interlinked dynamics and their implications for geographical development studies. The contribution from Martin Franz, Annika Trebbin and Mareike Felix and that from Martina Locher and Ulrike Müller-Böker both focus on economic dynamics through an investigation into two different strategies employed by international agents to securely access agricultural and environmental commodities. Access to commodities is ensured by establishing contract-based relationships with local farmers, through control of value chains and by securing access to land through the acquisition of land titles ("land grabbing"). Franz, Trebbin and Felix provide an insight into the strategies utilised by international agribusiness companies in India and West African countries to integrate small-scale farmers into value chains controlled by them, highlighting the potential advantages for both sides and obstacles to a smooth integration. Locher and Müller-Böker analyse the power relations and local perceptions related to land deals conducted by two European forest companies in Tanzania. They show the need for appropriate and transparent local institutional arrangements. Both articles provide evidence showing that it is not always easy for international agencies to acquire control of local commodities or resources. Instead, this process often involves strug- gles with a range of different local players for the right terms and conditions of a deal with unknown results.

Using the example of the Wakhi in the Karakoram, Andreas Benz's paper focuses on new mobility patterns, multilocal livelihoods and translocal developments. The Wakhi's already diversified livelihood activities, including farming activities, off-farm employment and labour migration, are today supplemented by intensified processes of mobility and migration, resulting in multi-local urban-rural livelihoods that span and connect geographically distant places. The paper shows how social ties in multi-local configurations have established important and highly effective local-to-local links by which "local" processes of change become interdependent with other "local" processes in a network of connected places.

Kirsten Koop and Sabin Bieri complement this issue with reflections on some theoretical concepts in the context of rural development. Kirsten Koop reflects on the rising interest in the territorial dimension of rural development in the Global South by contextualising and discussing the concept of "territorial development". She argues that the renewed interest in the territorial dimension of development is closely linked to the contemporary assumption that sub-national spatial entities constitute the adequate size for political rescaling and economic development. Koop highlights how the territorial approach towards development serves both mainstream ideologies on globalisation and competitiveness as well as alternative "post-development" thinking. Contextualising gender issues in the rise of high-value agriculture in the Global South, Sabin Bieri's paper examines the debate on feminisation. The shift towards high-value agricultural exports as a rural development strategy today plays a key role in creating wage labour and, notably, high levels of female employment in rural areas. Bieri emphasises, in her conceptual reflection, that any potential gender analysis has to consider complex development processes, especially in rural restructuring. She recommends even more detailed research in order to avoid inadequate simplifications that concepts like "feminisation of poverty" might suggest.

All papers in this issue show a worrying and re-emerging truth: (global) economic dynamics dominate rural contexts in the Global South - as well as increasingly in the Global North. The livelihoods, natural resources, and cultural and social aspects of local populations are directly affected. Economically weak actors with restricted capabilities - small-scale farmers and fishers, agricultural wage workers, harvesters, nomads and landless people - are further marginalised by these globalising dynamics, especially in a rural context. Political and institutional responses on global, national and local levels are required to regulate global dynamics in favour of those dependent on natural resources and to assist local producers to better cope with markets, thereby enhancing the path towards sustainable development. 